\title{
Effect of isoniazid, a haem inhibitor, on globin chain synthesis in reticulocytes from non-thalassaemic and $\beta$ thalassaemic subjects
}

\author{
G CHALEVELAKIS, A G YALOURIS, C LYBERATOS, Th ECONOMOPOULOS, \\ C ANASTASIOU, J HATZIIOANNOU, S RAPTIS
}

From the Second Department of Internal Medicine, University of Athens, Evangelismos Hospital, Athens, Greece

SUMMARY The effect of isonicotinic acid hydrazide (INH), a potent haem inhibitor, on globin chain synthesis was studied in reticulocytes from the following groups of patients: four non-thalassaemic patients (group i); five $\beta$ thalassaemia heterozygotes (group ii); three $\mathrm{Hb} \mathrm{S} / \beta$ thalassaemia heterozygotes (group iii); and two additional patients—one with homozygous $\beta$ thalassaemia and the other with thalassaemia intermedia (group iv). This was done to determine whether haem inhibitors depress $\alpha$ globin chain synthesis. The progressive increase of INH concentration $\left(10-40 \mathrm{mmol}^{-1}\right)$ in reticulocytes from a $\beta$ thalassaemia heterozygote resulted in a remarkable decrease of the $\alpha$ and $\beta$ chain synthesis, ranging from $80 \%$ to $97 \%$ and from $74 \%$ to $96 \%$ of control values, respectively, and in a gradual drop of $\alpha: \beta$ ratio from 1.87 to 1.38 . Furthermore, in the samples incubated with $40 \mathrm{mmol}$ $1^{-1} \mathrm{INH}$, a pronounced inhibition of globin chain synthesis $77(19 \%)$ for $\alpha$ chain and $67(27 \%)$ for $\beta$ or $\beta^{\mathrm{S}}$ chain) and a substantial drop of the $\alpha: \beta$ or $\beta^{\mathrm{S}}$ ratio in samples with INH (median $1 \cdot 16$ ) compared with that in samples without INH (median 1.70) were observed. The inhibitory effect of INH was significantly or completely corrected by adding exogenous haem.

It is suggested that haem inhibition and the resulting preferential diminution of $\alpha$ chain synthesis could provide a new approach to the treatment of homozygous $\beta$ thalassaemia with an excess of detrimental free $\alpha$ chain in erythroid cells.

In rabbit reticulocytes haemin was shown to stimulate globin synthesis ${ }^{1-5}$; inhibition of haem synthesis caused by various inhibitors such as ethanol ${ }^{6}$ or isonicotinic acid hydrazide $(\mathrm{INH})^{7-10}$ resulted in a pronounced decrease of globin synthesis, predominantly affecting the $\alpha$ chain. The existing studies are few and show conflicting results on the effect of INH or other haem inhibitors on globin chain synthesis in intact human reticulocytes. ${ }^{11-14}$ Furthermore, as far as we know, no study has included $\beta$ thalassaemic patients with an excess of free $\alpha$ chain in their reticulocytes. Because excess $\alpha$ chain is responsible for ineffective erythropoiesis and membrane damage of erythroid cells in these patients, ${ }^{15-17}$ selective inhibition of its synthesis may be of potential therapeutic value.

Accepted for publication 31 March 1989

\section{Material and methods}

Fourteen subjects, seven men and seven women, aged 25-60 years, gave their informed consent to the study. Four of them (group i) were non-thalassaemic. Two were haematologically normal (cases 1 and 3), one had iron deficiency anaemia (case 2), and one acquired haemolytic anaemia (case 4). Five patients (cases 5-9) were $\beta$-thalassaemia heterozygotes (group ii) and three (cases 10-12) had $\mathrm{Hb} \mathrm{S/ \beta}$-thalassaemia (group iii). The rest comprised two patients who had had their spleens removed, one of whom had homozygous $\beta$-thalassaemia (case 13) and the other (case 14) a mild form of thalassaemia with abundant haemoglobin in red cells, haemoglobin $F(\mathrm{HbF})$ of $80 \%$, and an $\alpha: \gamma$ ratio 1.40 (transfusion dependent before splenectomy). A family study is underway to elucidate further the accurate genotype of this case. Case 9 also had iron deficiency. The standard haematological determinations were performed as described by Dacie and Lewis. ${ }^{18}$ 
GLOBIN CHAIN SYNTHESIS

Peripheral blood $(15 \mathrm{ml})$ was immediately transferred to tubes containing heparin. After washing three times in reticulocyte saline $\left(\mathrm{NaCl} 130 \mathrm{mmol} \mathrm{1}^{-1}, \mathrm{MgCl} 7 \cdot 4\right.$ mmol $1^{-1}, \mathrm{KCl} 5 \mathrm{mmol}^{-1}$ ) at $4^{\circ} \mathrm{C}, 1 \cdot 2 \mathrm{ml}$ of cells were removed from the top layer and resuspended in reticulocyte saline at $4^{\circ} \mathrm{C}$. White cells were not removed because contamination of globin by labelled proteins derived from these cells is negligible in peripheral blood. ${ }^{19}{ }^{20}$ Four samples $(A, B, C, D)$ of 0.3 $\mathrm{ml}$ cells each were obtained. These cells were suspended in three volumes of incubation mixture. ${ }^{2122}$ The samples had been incubated for $\mathbf{3 0}$ minutes as follows: sample A was a control; sample B contained INH (Sigma Chemical Co) dissolved in the incubation mixture at a final concentration of $10-40 \mathrm{mmol} \mathrm{l}^{-1}$; sample $\mathrm{C}$ contained haemin (Sigma Chemical Co) dissolved (by shaking it in boiling hot water for five minutes) in $\mathrm{Na}_{2} \mathrm{CO}_{3}\left(100 \mathrm{mmol}^{-1}\right)$ buffer $(\mathrm{pH}: 8)$ at a final concentration of $0.4 \mathrm{mmol}^{-1}$; sample $\mathrm{D}$ contained both INH and haemin. Samples C and D were used only in cases $9,10,11,13,14$. Leucine $(5 \cdot 32$

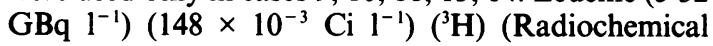
Centre, Amersham) (specific activity $2 \mathrm{TBq} \mathrm{mmol}^{-1}$ or $50 \mathrm{Ci} \mathrm{mmol}^{-1}$ ) was added to all samples.

To remove ethanol contained in the $\left({ }^{3} \mathrm{H}\right)$ leucine solution, its original solution was freeze dried and the solid rediluted in a small volume of incubation mixture. The incubation was stopped two hours later by adding a large volume of ice cold reticulocyte saline in which the cells were washed four times at $4^{\circ} \mathrm{C}$.

Globin preparation, globin chain separation, and the determination of radioactivity incorporated in globin chain were done as described previously. ${ }^{2023}$ Briefly, whole cell globin was prepared by the acid acetone method and the globin chains were separated using carboxylmethyl cellulose $\left(\mathrm{CM}_{23}\right.$-cellulose) in $8 \mathrm{M}$ urea and $50 \mathrm{mmol}^{-1}$ 2-mercaptoethanol with a linear $\mathrm{Na}_{2} \mathrm{HPO}_{4}$ (starting buffer $5 \mathrm{mmol}{ }^{-1}$ strong buffer: 40 $\mathrm{mmol} \mathrm{1}^{-1}$ ) gradient at $\mathrm{pH} 6.8$.

\section{DETERMINATION OF RADIOACTIVITY}

Aliquots of $0.2 \mathrm{ml}$ from each fraction were mixed with $1 \mathrm{ml}$ water and $10 \mathrm{ml}$ scintillation fluid ${ }^{24}$ and counted for 10 minutes. The results were expressed as total counts incorporated into each chain/minute/ml (cpm/ $\mathrm{ml}$ ). In the samples containing INH the determination of globin chain specific activity at $280 \mathrm{~nm}$ was unreliable, presumably because of interference of INH (maximal absorbance at $266 \mathrm{~nm}$ ). Exhaustive dialysis against $0.5 \%$ formic acid offered negligible improvement. In $\mathrm{Hb} \mathrm{S} / \boldsymbol{\beta}$-thalassaemic reticulocytes $\beta$ chain was absent or gave such low counts that any comparison with the other two chains $\left(\alpha, \beta^{s}\right)$ would have been unreliable. We therefore relied on the

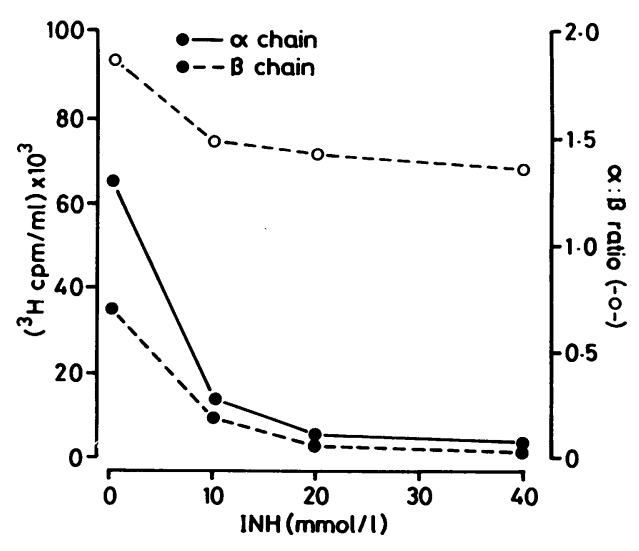

Fig 1 Effect of increased concentration of INH on radioactivity incorporated in $\alpha$ and $\beta$ globin chains in reticulocytes from one $\beta$-thalassaemia heterozygote (case 5).

changes of the $\alpha: \beta^{S}$ ratio for the estimation of the $\vec{c}$ inhibitory effect of INH.

Student's $t$ test, paired $t$ test, Wilcoxon's test for paired observations and the Spearman rank correlation coefficient test were used for statistical analysis.

\section{Results}

The results are given in tables $1-3$ and figs 1-2.

To determine the optimal INH concentration required to inhibit haem synthesis sufficiently, four $\stackrel{\varpi}{\varnothing}$ peripheral blood samples from a thalassaemic patient $\stackrel{\AA}{\AA}$ (case 5) were incubated with $0,10,20$ and $40 \mathrm{mmol}^{-1}$. $\overrightarrow{\overrightarrow{0}}$ The progressive increase of INH concentration resul- 3 ted in a gradual reduction of total counts of both $\alpha$ and $\vec{P}$ $\beta$ chains as well as of the $\alpha: \beta$ ratio (fig 1). The higher inhibitory concentration of $40 \mathrm{mmol} \mathrm{l}^{-1}$ was selected for the rest of the procedure.

EFFECT OF INH ON GLOBIN CHAIN SYNTHESIS INH (40 mmol $\left.\mathrm{m}^{-1}\right)$ caused a pronounced decrease of $\frac{\mathrm{O}}{3}$ total counts incorporated in globin compared with those of the control samples (50\% up to $97 \%$ (77 (SD $19) \%$ ) for $\alpha$ chain and $10 \%$ up to $96 \%$ (67 (27)\%) for $\beta \frac{7}{O}$ or $\beta^{\mathrm{s}}$ chain). The inhibition of $\alpha$ chain synthesis was stronger than that of $\beta$ or $\beta^{s}$ chain, resulting in a $N$ remarkable decrease $(\mathrm{p}<0.01)$ of the $\alpha$ : $\beta$ or $\beta^{\mathrm{s}}$ ratio in $N$ the presence of INH (median: $1 \cdot 16$, range $0-4.63$ ) compared with the initial values (median $1 \cdot 70$, range $\omega$ $0 \cdot 80-5.90)$ (table 1$)$ and pronounced $(t=4 \cdot 13$, $\mathrm{p}<0.05$ ) improvement of globin chain imbalance in $\beta$ thalassaemic patients of group ii (table 2). The $\mathbb{E}$ observed differences in the inhibitory effect of INH :among the three groups of patients were not significant, possibly because of the small number of 
Table 1 Effect of $40 \mathrm{mmol}^{-1}$ INH on radioactivity incorporated into globin chains in reticulocytes of 14 patients

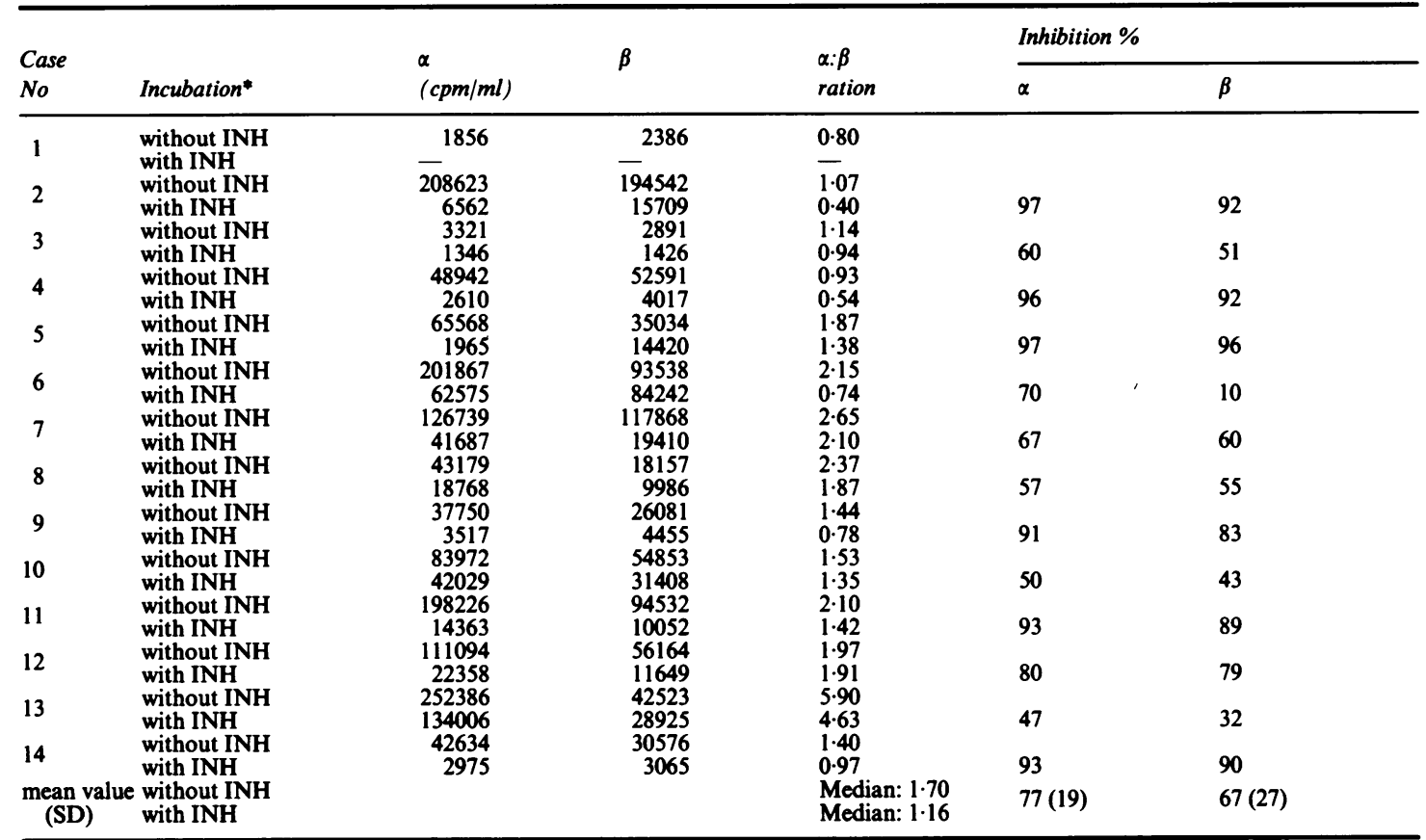

*In $\mathrm{HB}^{\mathrm{s}} / \boldsymbol{\beta}$ thalassaemia heterozygotes (cases $\left.10,11,12\right) \beta$ chain was replaced by $\beta^{s}$ and in case 14 by $\gamma$ chain.

patients involved (table 2). In iron deficiency anaemia (case 2) and heterozygous $\beta$ thalassaemia and iron deficiency (case 9) a pronounced decrease of the $\alpha: \beta$ ratio was observed (table 1). There was no significant correlation, however, among all cases with the

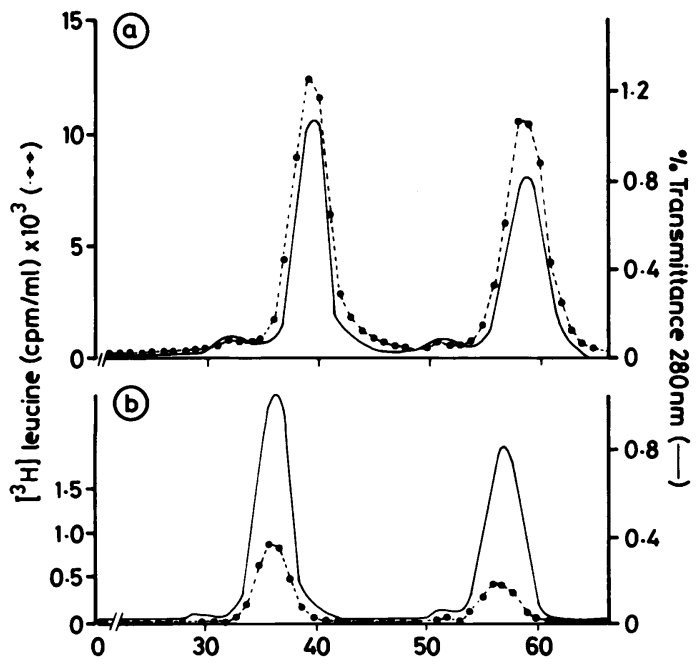

Fig 2 Globin chain synthesis in reticulocytes incubated (a) without INH, (b) with INH $\left(40 \mathrm{mmol} / \mathrm{l}^{-1}\right)$ (case 4). inhibitory effect of INH and serum iron values. This effect was also not significantly correlated with other haematological variables such as the haematocrit, haemoglobin concentration, or reticulocyte number.

\section{EFFECTS OF HAEMIN $\left(0.4\right.$ MMOL L $\left.{ }^{-1}\right)$ ON $\alpha$ AND $\beta$} $\left(\beta^{S}\right)(\gamma)$ CHAIN SYNTHESIS

In cases 10 and 13 haemin stimulated the synthesis of both $\alpha$ and $\beta\left(\beta^{\mathrm{s}}\right)$ globin chains equally (90\% in case 10 and $21 \%$ in case 13 ); in cases 9 and 14 a much stronger stimulation of globin chains (138-143\% for $\alpha$ chain and $64-84 \%$ for $\beta$ or $\gamma$ chain) was observed with a remarkable increase of the $\alpha: \beta$ or $\alpha: \gamma$ ratios. By contrast, in case 11 the synthesis of both globin chains was slightly reduced by $8 \%$. When both haemin and INH were added the inhibitory effect of INH was partially (cases 10,13 ) or completely (cases 9,14 ) reversed. In case 9 with heterozygous $\beta$ thalassaemia and iron deficiency the addition of haemin resulted in an overcorrection of the decrease in $\alpha$ and $\beta$ globin chain synthesis (table 3 ).

\section{Discussion}

INH inhibits haem synthesis by depressing aminolevulinic acid (ALA) synthetase, ${ }^{525}$ which is the first and rate limiting enzyme in the haem synthesis pathway, resulting in a depletion of intracellular haem. 
Table 2 Changes in mean values of the $\alpha: \beta$ or $\beta^{s}(\gamma)$ ratios and inhibition of the $\alpha, \beta$, and $\beta^{s}(\gamma)$ chain synthesis in reticulocytes from groups I, II, III, and IV

\begin{tabular}{|c|c|c|c|c|c|c|}
\hline \multirow[b]{2}{*}{ Group } & \multirow[b]{2}{*}{ Sample } & \multirow[b]{2}{*}{$\alpha: \beta$} & \multirow[b]{2}{*}{$\alpha: \beta^{n}$} & \multicolumn{3}{|c|}{ Inhibition \% (SD) } \\
\hline & & & & $\alpha$ & $\beta$ & $\beta^{s}$ \\
\hline & & $\mathrm{cpm} / \mathrm{ml}(\mathrm{SD})$ & & & & \\
\hline $\begin{array}{l}\text { (i) }(n=3) \text { : } \\
\text { Range }\end{array}$ & $\mathbf{A}$ & $\begin{array}{l}1.05(0.10) \\
(1.14-0.93)\end{array}$ & & & & \\
\hline Range & B & $\begin{array}{r}0.62(0.30) \\
(0.94-0.40)\end{array}$ & & $\begin{array}{r}84(21) \\
(60-97)\end{array}$ & $\begin{array}{r}78(24) \\
(51-92)\end{array}$ & \\
\hline $\begin{array}{l}\text { (ii) }(n=5) \text { : } \\
\text { Range }\end{array}$ & A & $\begin{array}{r}2.10(0.46) \\
(2.65-1.44)\end{array}$ & & & & \\
\hline Range & B & $\begin{array}{l}1.37(0.61) \\
(2 \cdot 10-0.74)\end{array}$ & & $\begin{array}{r}76(17) \\
(57-97)\end{array}$ & $\begin{array}{r}61(30) \\
(10-96)\end{array}$ & \\
\hline $\begin{array}{l}\text { (iii) }(\mathrm{n}=3) \text { : } \\
\text { Range }\end{array}$ & $\mathbf{A}$ & & $\begin{array}{l}1.86(0.30) \\
(2.10-1.53)\end{array}$ & & & \\
\hline Range & B & & $\begin{array}{l}1.56(0.30) \\
(1.91-1.35)\end{array}$ & $\begin{array}{r}74(28) \\
(50-93)\end{array}$ & & $\begin{array}{r}70(24) \\
(43-89)\end{array}$ \\
\hline $\begin{array}{l}\text { iv }(n=2) \text { : } \\
\text { Range }\end{array}$ & $\mathbf{A}$ & & $\begin{array}{r}3.65(3.18) \\
(5.90-1.40)\end{array}$ & & & \\
\hline Range & B & & $\begin{array}{r}2.80(2.58) \\
(4.63-0.97)\end{array}$ & $\begin{array}{r}70(32) \\
(47-93)\end{array}$ & $\begin{array}{r}61(41) \\
(32-90)\end{array}$ & \\
\hline
\end{tabular}

Previous studies on the effect of INH and other haem inhibitors on human globin chain synthesis are few and the results conflicting. Thus a remarkable depression of the $\alpha: \beta$ ratio was found in normal reticulocytes incubated in the presence of lead ${ }^{11}$ and in reticulocytes from patients with $\beta$ thalassaemia or $\mathrm{Hb}$ $\mathrm{S} / \beta$ thalassaemia incubated with ethanol. ${ }^{12}$ Furthermore, in sideroblastic anaemia, a haem deficiency condition, a diminished $\alpha: \beta$ synthetic ratio has been found. ${ }^{2627}$ The addition of haem to the incubation mixture stimulated considerably the synthesis of both globin chains and particularly that of the $\alpha$ chain, resulting in an increase of the $\alpha: \beta$ ratio.

More recently, however, it has been suggested that in haem deficiency conditions such as sideroblastic $\overrightarrow{0}$ and iron deficiency anaemia or after specific inhibition 0 of haem synthesis with INH $\left(4 \mathrm{mmol} \mathrm{l}^{-1}\right)$, the $\alpha$. synthetic ratio remains within the normal range without an important stimulatory effect of exogenous haem on globin chain synthesis. ${ }^{13}$

Our work has clearly shown that INH, a potent $\stackrel{\otimes}{\AA}$ haem inhibitor, significantly inhibits globin chain synthesis up to $97 \%$ of control values in non-thalassaemic and thalassaemic reticulocytes (table 1). This

Table 3 Effect of INH and hemin on $\alpha$ and $\beta\left(\beta^{s}\right)(\gamma)$ globin chain synthesis and $\alpha: \beta\left(\beta^{s}\right)(\gamma)$ ratio in reticulocytes from heterozygous $\beta$ thalassaemia $\mathrm{Hb} S / \beta$-thalassaemia heterozygotes, homozygous $\beta$ thalassaemia and thalassaemia intermedia.

\begin{tabular}{|c|c|c|c|c|c|c|c|c|}
\hline \multirow[b]{2}{*}{ Case No } & \multirow[b]{2}{*}{ Sample } & \multirow{2}{*}{$\begin{array}{l}\text { INH } \\
(40 \mathrm{mmol} \\
\left.\times l^{-1}\right)\end{array}$} & \multirow{2}{*}{$\begin{array}{l}\text { Haemin } \\
(0 \cdot 4 \mathrm{mmol} \\
\left.\times l^{-1}\right)\end{array}$} & \multirow[b]{2}{*}{$\alpha$} & \multirow[b]{2}{*}{$\beta$} & \multirow[b]{2}{*}{$\alpha: \beta$} & \multicolumn{2}{|c|}{ Change \% } \\
\hline & & & & & & & $\alpha$ & $\beta$ \\
\hline 9 & $\begin{array}{l}\text { A } \\
\text { B } \\
\text { C } \\
\text { D }\end{array}$ & $\begin{array}{l}- \\
+ \\
+\end{array}$ & $\begin{array}{l}- \\
\bar{t} \\
+\end{array}$ & $\begin{array}{c}(\mathrm{cpm} / \mathrm{ml}) \\
37750 \\
3517 \\
92052 \\
51298\end{array}$ & $\begin{array}{r}26081 \\
4455 \\
49678 \\
31628\end{array}$ & $\begin{array}{l}1.44 \\
0.78 \\
1.91 \\
1.62\end{array}$ & $\begin{array}{l}- \\
-91 \\
+143 \\
+35\end{array}$ & $\begin{array}{l}- \\
-83 \\
+84 \\
+21\end{array}$ \\
\hline $10^{*}$ & $\begin{array}{l}\mathbf{A} \\
\mathbf{B} \\
\mathbf{C} \\
\mathbf{D}\end{array}$ & $\begin{array}{l}- \\
+ \\
+\end{array}$ & $\begin{array}{l}- \\
+ \\
+\end{array}$ & $\begin{array}{r}83972 \\
42029 \\
159926 \\
53408\end{array}$ & $\begin{array}{r}54853 \\
31408 \\
103984 \\
32898\end{array}$ & $\begin{array}{l}1.53 \\
1.35 \\
1.53 \\
1.62\end{array}$ & $\begin{array}{l}- \\
-50 \\
+90 \\
-37\end{array}$ & $\begin{array}{l}- \\
-43 \\
+90 \\
-41\end{array}$ \\
\hline $11^{*}$ & $\begin{array}{l}\text { A } \\
\text { B } \\
\text { C } \\
\text { D }\end{array}$ & $\begin{array}{l}- \\
+ \\
+\end{array}$ & $\begin{array}{l}- \\
\overline{+} \\
+\end{array}$ & $\begin{array}{r}198226 \\
14363 \\
181423 \\
17793\end{array}$ & $\begin{array}{l}94532 \\
10052 \\
87080 \\
11235\end{array}$ & $\begin{array}{l}2 \cdot 10 \\
1.42 \\
2 \cdot 10 \\
1 \cdot 58\end{array}$ & $\begin{array}{l}- \\
-93 \\
-8 \\
-91\end{array}$ & $\begin{array}{l}- \\
-89 \\
-8 \\
-88\end{array}$ \\
\hline 13 & $\begin{array}{l}\mathbf{A} \\
\mathbf{B} \\
\mathbf{C} \\
\mathbf{D}\end{array}$ & $\begin{array}{l}- \\
+ \\
+\end{array}$ & $\begin{array}{l}- \\
\overline{+} \\
+\end{array}$ & $\begin{array}{l}252386 \\
134006 \\
304827 \\
199415\end{array}$ & $\begin{array}{l}42523 \\
28925 \\
51671 \\
30006\end{array}$ & $\begin{array}{l}5.90 \\
4.63 \\
5.89 \\
6.64\end{array}$ & $\begin{array}{l}- \\
-47 \\
+21 \\
-21\end{array}$ & $\begin{array}{l}- \\
-32 \\
+21 \\
-30\end{array}$ \\
\hline $14^{*}$ & $\begin{array}{l}\text { A } \\
\text { B } \\
\text { C } \\
\text { D }\end{array}$ & $\begin{array}{l}\overline{-} \\
+ \\
+\end{array}$ & $\begin{array}{l}- \\
\overline{+} \\
+\end{array}$ & $\begin{array}{r}42634 \\
2975 \\
101834 \\
47625\end{array}$ & $\begin{array}{r}30576 \\
3065 \\
50290 \\
28885\end{array}$ & $\begin{array}{l}1.40 \\
0.97 \\
2.00 \\
1.65\end{array}$ & $\begin{array}{l}- \\
-93 \\
+138 \\
+11\end{array}$ & $\begin{array}{l}- \\
-90 \\
+64 \\
-6\end{array}$ \\
\hline
\end{tabular}

$* \beta$ chain was replaced by $\beta^{*}$ and by $\gamma$ in case 14 . 
finding is consistent with the earlier reported inhibitory effect of INH on total globin or globin chain synthesis in animal reticulocytes. ${ }^{5810}$ The constant decrease of the $\alpha: \beta$ or $\beta^{\mathrm{s}}(\gamma)$ ratio caused by INH in all 14 subjects studied and the inverse relation between the $\alpha: \beta$ ratio and INH concentration (10-40 mmol $1^{-1}$ ) indicate a selective inhibition of $\alpha$ chain synthesis. Although the concentrations of INH used in vitro for inhibition of globin chain synthesis are much higher than those obtained in clinical practice, it has nevertheless been suggested that chronic exposure in vivo at lower INH concentrations may also have a similar effect. ${ }^{10}$

The addition of exogenous haem in our experiments partially or completely reversed the inhibitory effect of INH. The stimulatory effect of haemin on $\alpha$ and $\beta\left(\beta^{\text {s }}\right)$ $(\gamma)$ globin chain synthesis was either the same for $\alpha$ and $\beta\left(\beta^{S}\right)$ (cases 10,13 ) or stronger for $\alpha$ chain (cases 9,14 ); the correction of the inhibitory effect of INH by haemin was always much stronger for $\alpha$ chain (table 3 ). This phenomenon was more evident in case 9 with both heterozygous $\beta$ thalassaemia and iron deficiency. The observed inhibitory effect of haemin on globin synthesis in case 11 is difficult to interpret. Likewise, a similar unexplained finding was reported by other authors in human reticulocytes. ${ }^{1326}$

The controversy over the association between haem and globin chain synthesis in haem deficient reticulocytes in man must be cautiously studied before being attributed to methodological differences alone. It is essential, however, (a) to ensure that haemin is completely dissolved; (b) to preincubate the cells for at least 30 minutes (to decrease intracellular haem concentration) before adding the labelled aminoacid; and (c) to rely only on samples with a good chromatographic separation and high incorporation of labelled amino acid.

In conclusion, INH effectively inhibits globin chain synthesis with preferential inhibition of $\alpha$ chain synthesis in all cases studied and a noticeable correction of the globin chain imbalance in $\beta$ thalassaemic reticulocytes. The inhibitory effect of INH is reversed by adding exogenous haem. These findings suggest that there is a close relation between haem and globin chain synthesis in reticulocytes in man which should be investigated further because a new approach to the treatment of homozygous $\beta$ thalassaemia with an excess of detrimental free $\alpha$ chain in erythroid cells may be possible.

We thank Mrs Mary Methenitou for her skilful technical assistance.

This investigation was supported by a grant from the University of Athens.

\section{References}

1 Grayzel AI, Hörchner P, London IM. The stimulation of globin synthesis by haem. Proc Natl Acad Sci USA 1966;55:650-5.

2 Adamson SD, Herbert E, Kemp SF. Effects of haemin and other porphyrins on protein synthesis in a reticulocyte lysate cell-free system. J Mol Biol 1969;42:247-58.

3 Maxwell CR, Rabinovitz M. Evidence of an inhibitor in the control of globin synthesis by hemin in a reticulocyte lysate. Biochem Biophys Res Commun 1969;35:79-85.

4 Legon S, Jackson RT, Hunt T. Control of protein synthesis in reticulocyte lysates by haemin. Nature 1973;241:150-2.

5 Neuwirt J, Ponka P. Regulation of haemoglobin synthesis. Hague: Martin Nijhoff, 1977:64-130.

6 Freedman ML, Cohen MS, Rosman J, Forte FJ. Ethanol inhibition of reticulocyte protein synthesis: the role of haem. Br J Haematol 1975;30:351-63.

7 Ponka P, Neuwirt J. The use of reticulocytes with high non-haem iron pool for studies of regulation of haem synthesis. $\mathrm{Br} \mathrm{J}$ Haematol 1970;19:593-604.

8 Fuhr JE, Gengozian N. Coordination of heme and globin synthesis in primate reticulocytes. Biochim Biophys Acta 1973;320:53-8.

9 Giglioni B, Gianni AM, Comi P, Ottolengthi S, Rungger D. Translational control of globin synthesis by haemin in xenopus oocytes. Nature 1973;246:99-102.

10 Franco RS, Hogg JW, Martelo OJ. The effect of INH-inhibited heme synthesis on globin synthesis. J Lab Clin Med 1979;93:679-86.

11 White JM, Harvey DR. Defective synthesis of $\alpha$ and $\beta$ globin chains in lead poisoning. Nature 1972;236:71-3.

12 Adams JG, Newman MV, Steinberg MH. Post translational modification of globin synthesis in vitro. Blood 1977;(suppl): $1-100$.

13 Peters RE, May A, Jacobs A. Globin chain synthesis ratios in sideroblastic anaemia. Br J Haematol 1983;53:201-9.

14 Adams JG, Newman MV, Steinberg MH, Desimone J. Effect of lead and ethanol upon gamma-globin synthesis in sickle reticulocytes. Am J Med Sci 1986;292:299-305.

15 Fessas P. Inclusions of hemoglobin in erythroblasts and erythrocytes of thalassemia. Blood 1963;21:21-32.

16 Fessas P, Loukopoulos D. Alpha-chain of human $\mathrm{Hb}$ : occurrence "in vitro". Science 1964;143:590-1.

17 Nathan DG, Gunn RB. Thalassemia: the consequences of unbalanced hemoglobin synthesis. Am J Med 1966;41:815-30.

18 Dacie JV, Lewis SM. Practical haematology. 5th ed. Edinburgh: Churchill-Livingstone, 1975.

19 Chalevelakis G, Clegg JB, Weatherall DJ. Imbalanced globin chain synthesis in heterozygous $\beta$-thalassaemic bone marrow. Proc Natl Acad Sci USA 1975;72:3853-7.

20 Chalevelakis G, Glegg JB, Weatherall DJ. Globin synthesis in normal human bone marrow. Br J Haematol 1976;34:535-57.

21 Lingel JB, Borsook M. A comparison of aminoacid incorporation into the hemoglobin and ribosomes of marrow erythroid cells and circulating reticulocytes of severely anemic rabbits. Biochemistry 1963;2:309-24.

22 Weatherall DJ, Clegg JB, Na-Nakorn S, Wasi P. The pattern of disordered haemoglobin synthesis in homozygous and heterozygous $\beta$-thalassaemia. $\mathrm{Br}$ J Haematol 1969;16:251-67.

23 Clegg JB, Naughton MA, Weatherall DJ. Abnormal human haemoglobins: separation and characterization of the $\alpha$ - and $\beta$-chains by chromatography and the determination of two new variants, $\mathrm{Hb}$ Chesapeak $\mathrm{Hb} \mathrm{J}$ (Bangkok). J Mol Biol 1966;19:91-108.

24 Bray GA. A simple efficient liquid scintillator for counting aqueous solutions in a liquid scintillation counter. Anal Biochem 1960;1:279-85.

25 Biehl JP, Vilter RW. Effect of isoniazid on pyridoxine metabolism. JAMA 1954;156:1549-54.

26 White JM, Brain MC, Ali MAM. Globin synthesis in sideroblastic anaemia. I. $\alpha$ and $\beta$ peptide chain synthesis. $B r J$ Haematol 1971;20:263-75.

27 White JM, Ali MAM. Globin synthesis in sideroblastic anaemia. II. The effect of pyridoxine, $\delta$-aminolaevulinic acid and haem in vitro. Br J Haematol 1973;24:481-9.

Requests for reprints to: Dr G Chalevelakis, Second Department of Internal Medicine, Evangelismos Hospital, Ipsilandou 45-49, GR 115110 Athens, Greece. 